\title{
Length-Weight Relationship, Condition Factor and Otolith shape of Marble Goby (Oxyeleotris marmorata) at Sermo Reservoir, Yogyakarta
}

\author{
Rury Nur Aini, Namastra Probosunu, Eko Setyobudi* \\ Department of Fishery, Faculty of Agriculture, Universitas Gadjah Mada \\ Flora Street, Building A-4, Bulaksumur, Yogyakarta
}

\begin{abstract}
This research aimed to know the length-weight relationship, condition factor, and otolith shape of marble goby (Oxyeleotris marmorata Blkr.) at Sermo Reservoir Yogyakarta. In total 211 samples (95 males and 116 females) were collected using gillnet and folded trap (bubu). Each sample was observed for sex determination, and then measured its total length, body weight, and otoliths diameter. The data were analyzed to determine the length and weight distribution, length-weight relationship, condition factor, and length-otolith diameter relationship. The result showed that the total length of the male was ranged $12.0-38.2 \mathrm{~cm}$ and female was ranged 12.2-44.5 cm. The weight of the male was ranged 21.0-704.8 $\mathrm{g}$ and female was ranged 21.1-1593.7 g. Both male and female have positive allometric growth with the equation $\mathrm{W}=0.0056 \mathrm{~L}^{3.2894}$ for male and $\mathrm{W}=0.0051 \mathrm{~L}^{3.311}$ for female. Condition factor was ranged $0.787-1.313$ for male and 0.800-1.379 for female, and the majority of fish has a good condition ( $\mathrm{Kn} \geq 0.95$ more than $50 \%$ ). The shape of otolith edge was sinuate surrounded with regular wave-like curves, the diameter was increased in line with increasing of total body length by an equation of $\mathrm{Y}=0.2335+0.0248 \mathrm{X}$ $(\mathrm{r}=0.938)$.
\end{abstract}

\section{Introduction}

Sermo Reservoir, the first artificial lake in Yogyakarta, has several important roles such as agriculture water supply, sources of clean water and fisheries. To increase fish population, several species of fish were introduced and restocked during the initial stage of inundation. Marble goby (O. marmorata) is one of the freshwater fish that can be found from Thailand to Indonesia [1]. The species was introduced in Sermo Reservoir at an unknown period and process. Marble goby catch in Sermo Reservoir was still below other species, such as tilapia or red devil. Marble goby (Oxyeleotris marmorata Blkr.) was predatory fish, feed mainly small fishes and crustacean [2]. Marble goby is a carnivore at the top of pyramid hence fewer number compare to other organisms at lower trophic levels [3]. Therefore, it might have

*Corresponding author: setyobudi_dja@ugm.ac.id 
potential as a natural predator to control other fish populations. Previously, tilapia was dominant fish species, comprised of more than $50 \%$ of fish catches in Sermo Reservoir [4], but shifted over by red devil (Amphilophus labiatus) which was fast growth and become dominant species, however, it has low economic value. As the red devil population is expected to be increasing annually, it was necessary to control their population.

The length-weight relationship, condition factor, and growth are required for fish population study, and as basic fundamental data for fishery resources management. Lengthweight data is beneficial to measure the total weight of caught fish, while length-frequency might indicate survival rate or the health of the fish population, particularly to determine the fish relative condition [5]. Condition factor or ponderal index was used to measure the fitness and physical capacity of fish for their survival and reproduction. Fish age and growth are part of the population dynamic parameter which important to measure fish stock, required as a basic consideration in fisheries resources management.

\section{Research Method}

Fish samples were taken from fishers from December 2013 to May 2014 in Sermo Reservoir (Figure 1), caught using gill net at various mesh sizes (1-2.5 inches) and fish trap.

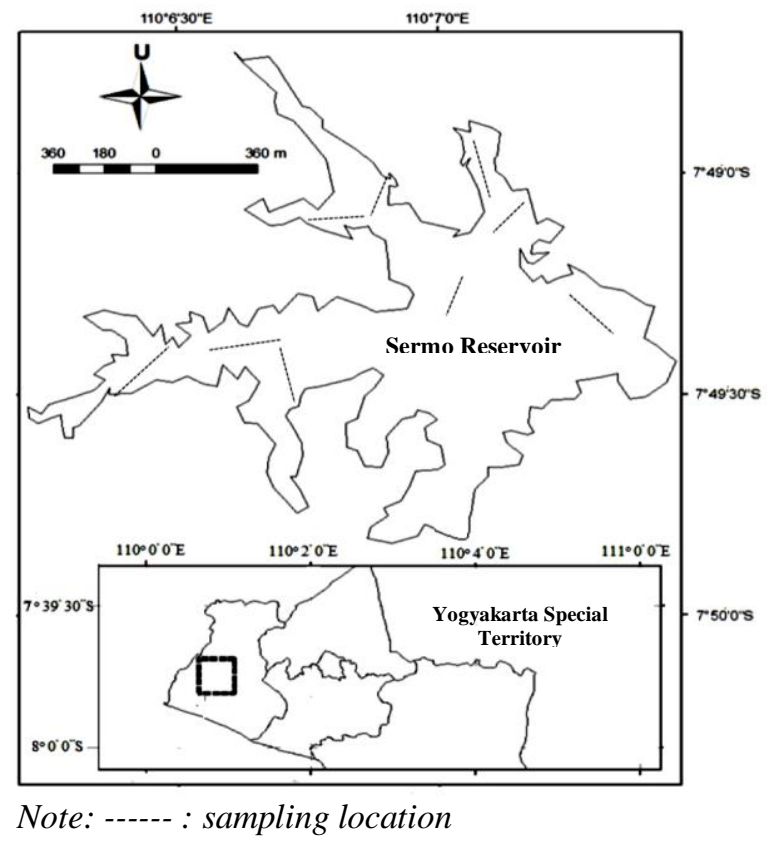

Fig 1. Location of Sermo Reservoir and Sampling Location

The data were analyzed to determine the length and weight frequency distribution, lengthweight relationship, and condition factor. Length-weight relationship analysis was performed using linear regression correlation previously used by Biswas [6]. Calculation of $b$ value was performed using t-test at 0.05 significance to ensure the significant difference of fish growth from isometric growth, by which the result was used to measure those two parameters, hypothesized as $b=3$ to indicate isometric pattern that the weight increase with length; and $b \neq 3$ represents allometric pattern that the growth of length and weight increase not in 
concomitant pattern. Fulton's condition factor was used for isometric fish growth type, calculated using formula as follows [7]:

$$
\mathrm{K}=\left(W / L^{3}\right) \times 100
$$

with:

$$
\begin{array}{ll}
\mathrm{K} & =\text { Fulton's condition factor, } \\
\mathrm{W} & =\text { fish weight }(\text { gram }), \\
\mathrm{L} & =\text { total fish length }(\mathrm{cm})
\end{array}
$$

The condition factor of allometric fish growth was calculated in relative by the

\begin{tabular}{|c|c|}
\hline $\mathrm{Kn}$ & $=$ relative condition factor, \\
\hline W & $=$ fish weight (gram), \\
\hline $\begin{array}{l}\mathrm{L} \\
\mathrm{a} \text { and } \mathrm{b}\end{array}$ & $\begin{array}{l}=\text { total fish length }(\mathrm{cm}), \\
=\text { constant }\end{array}$ \\
\hline
\end{tabular}
formula described previously [8] as follows:

$$
\mathrm{Kn}=(W / a L b) \times 100
$$

with:

\section{Results}

\subsection{Length and weight frequency distribution}

The total length of marble goby ranged from 12.0 to $44.5 \mathrm{~cm}$. Most of the male marble goby $(75.79 \%)$ sized $14.1-24.0 \mathrm{~cm}$, while most of the female $(93.96 \%)$ sized $14.1-26.0 \mathrm{~cm}$. Only a few fish have a total length of more than $30.0 \mathrm{~cm}(<7.5 \%)$ (Fig. 2).

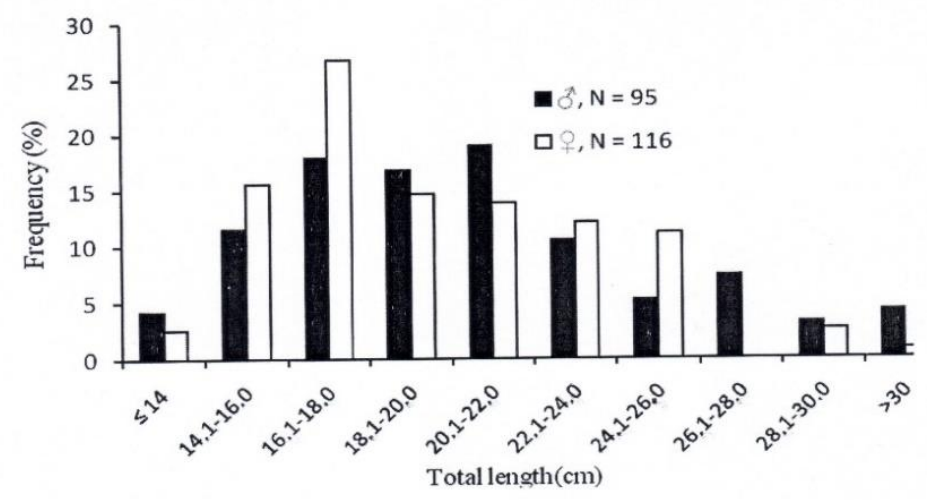

Fig. 2. Length distribution of $O$. marmorata in Sermo Reservoir.

The weight of marble goby ranged from 21.0-704.8 $\mathrm{g}$ for the male, and 21.1-1593.7 $\mathrm{g}$ for the female, respectively. Most of the male and female fish, $66.32 \%$ and $74.14 \%$, respectively, had a weight range at 40.01-160.00 g, and no fish was found lower than 20.0 g. (Fig. 3). 


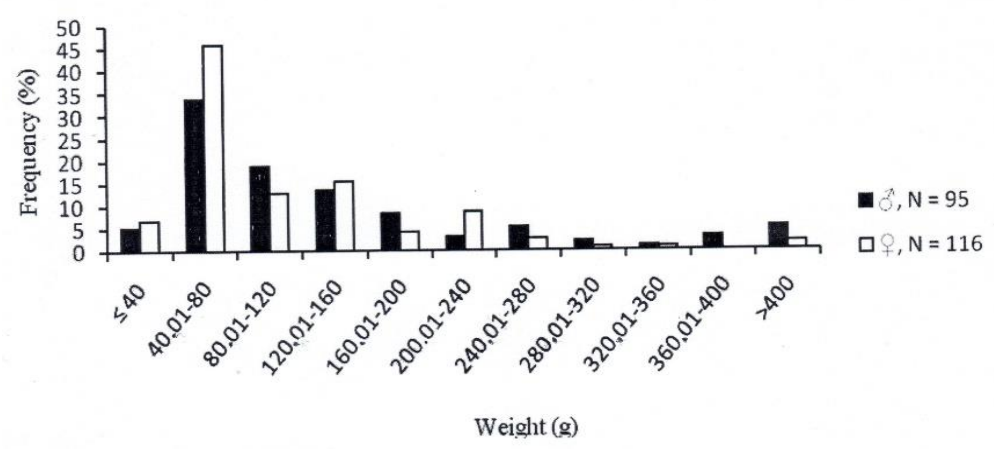

Fig. 3. Weight distribution of O. marmorata in Sermo Reservoir.

\subsection{Length-weight relationship}

Length-weight relationship of male and female fish followed equation of $\mathrm{W}=0.0056 \mathrm{~L}^{3.2894}$ $(\mathrm{r}=0.992)$ and $\mathrm{W}=0.0051 \mathrm{~L}^{3.311}(\mathrm{r}=0.988)$, respectively. Data analysis using t-test indicated marble goby in Sermo Reservoir had an allometric growth pattern with $b \neq 3(\alpha=5 \%)$, and determination coefficient $\left(\mathrm{R}^{2}\right)$ for the male of 0.9834 and female of 0.9769 (Fig. 4).

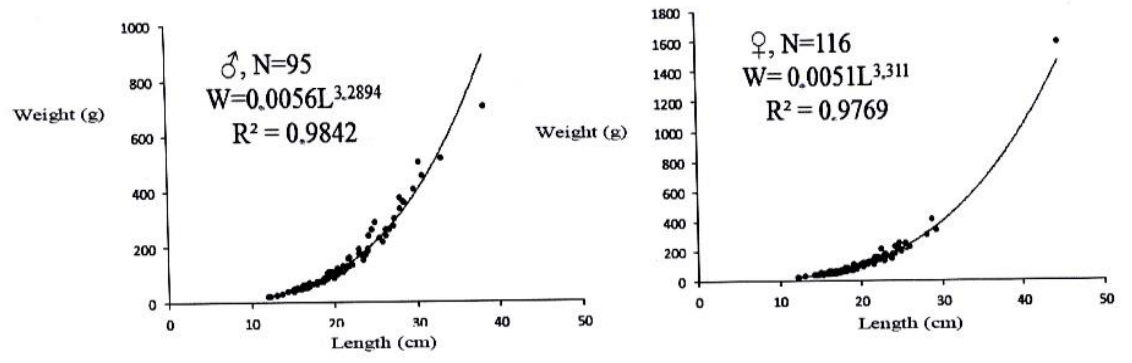

Fig. 4. Length-weight relationship of $O$. marmorata in Sermo Reservoir

\subsection{Condition factor}

Relative condition factor $(\mathrm{Kn})$ of male and female fish was different each month, ranged at $0.787-1.313$ with a mean of 0.999 for male and $0.800-1.379$ with a mean of 1.005 for female (Fig. 5).

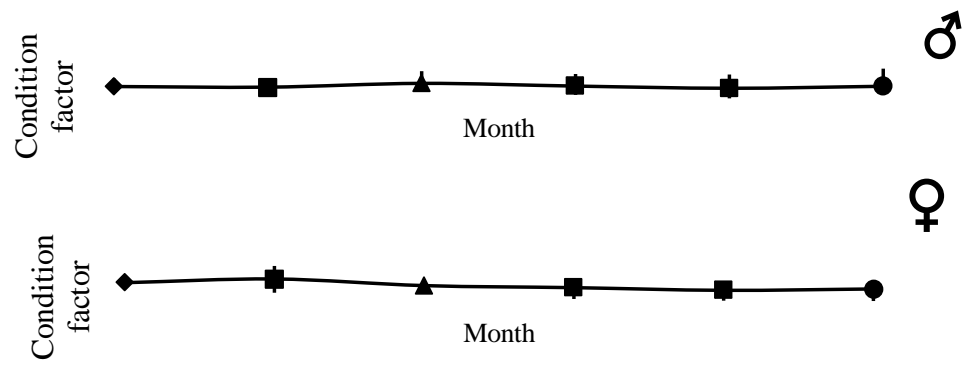

Fig. 5. Condition factor of O. marmorata caught in Sermo Reservoir 
There was a slight fluctuation of the mean of $\mathrm{Kn}$ for male and female fish during observation, which is 0.966-1.053 and 0.972-1.154, respectively. The lowest Kn was found in April for both male and female fish; however, the highest Kn was found in a different time, i.e. February for male and January for female. Kn was classified into three groups; $<0.95$ for fair condition, 0.95-1.05 for good condition, and >1.05 for very good condition represented Kn proportion based on sex (Figure 6).
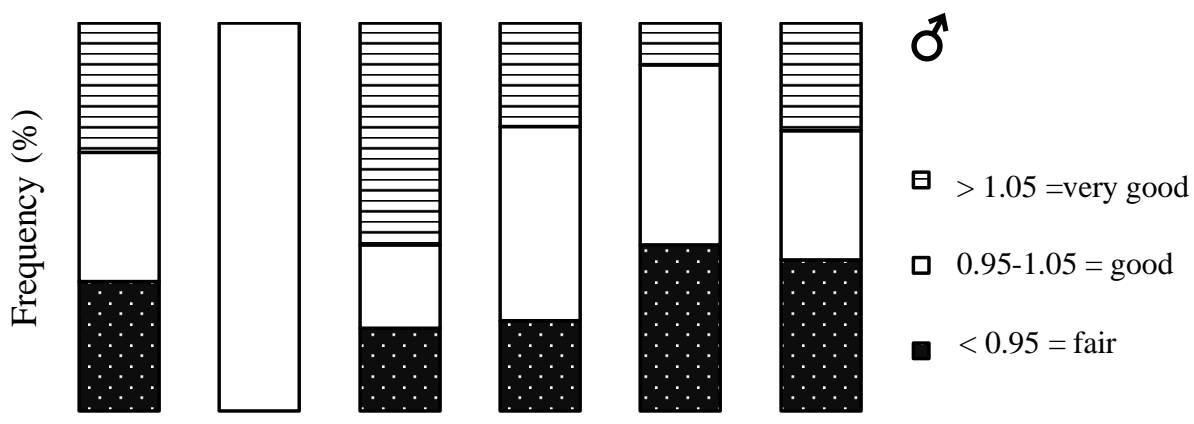

Month
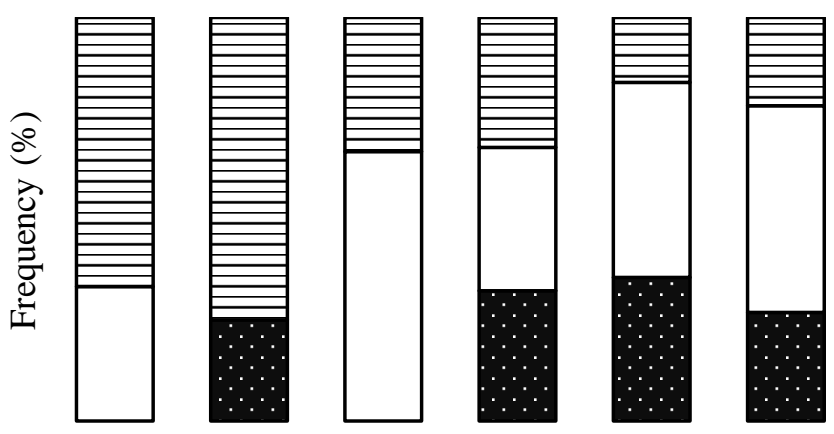

ㅇ

口 $>1.05=$ very good

ㅁ $0.95-1.05=\operatorname{good}$

- $<0.95=$ fair

\section{Month}

Fig. 6. Distribution of condition factor of $O$. marmorata in Sermo Reservoir.

Relative condition factor data showed that the highest proportion of male and female in fair condition $(\mathrm{Kn}<0.95)$ occurred in April of $42.86 \%$ and $35.48 \%$, respectively, while their highest percentage in good condition $(0.95 \leq \mathrm{Kn} \leq 1.05)$ occurred in January for male $(100 \%)$ and February for female $(66.67 \%)$. The highest proportion of $\mathrm{Kn}$ in very good condition $(\mathrm{Kn}>1.05)$ was obtained in February for male $(57.14 \%)$ and January for female $(75 \%)$.

\subsection{Otolith shape and total length-otolith diameter relationship}

The diameter of otolith ranged from $0.49-1.22 \mathrm{~cm}$ and a mean of $0.73 \mathrm{~cm}$. The shape was similar to the ovate type and medium thickness. The shape of otolith edge was sinuate surrounded with regular wave-like curves (Figure 7). 


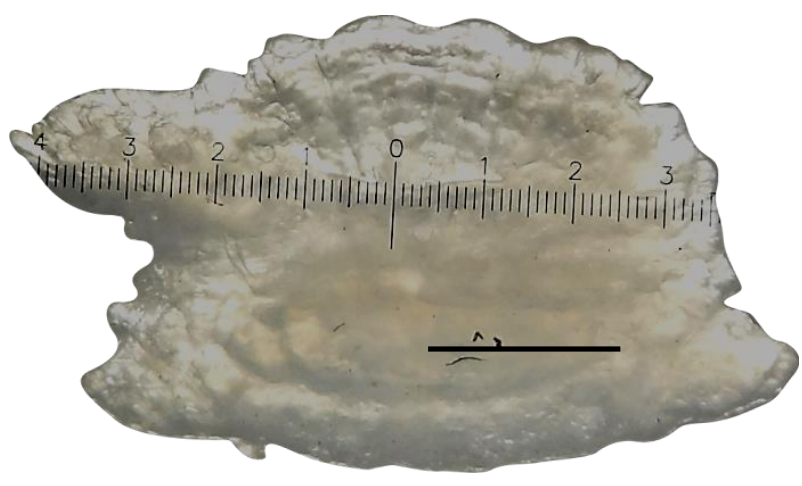

Fig. 7. Otolith of $O$. marmorata $($ bar $=2 \mathrm{~mm})$

Marble goby otolith was ovate shaped with sinuate edge and moderate thickness, the diameter was increased in line with increasing of total body length by an equation of $\mathrm{Y}=0.2335+0.0248 \mathrm{X}(\mathrm{r}=0.938)$. The total length was linearly followed by larger otolith diameter $\left(\mathrm{R}^{2}=0.8799\right)$ (Figure 8$)$.

$$
\begin{gathered}
Y=0.0248 X+0.2335 \\
R^{2}=0.8799
\end{gathered}
$$

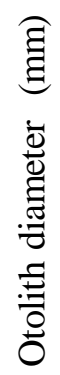

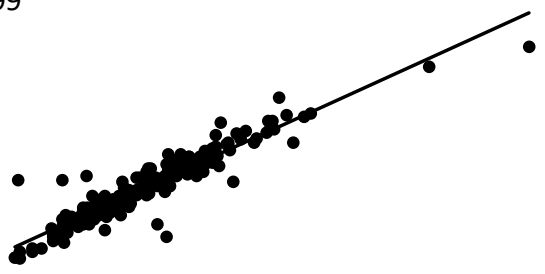

Total length $(\mathrm{cm})$

Fig. 8. Total length-otolith diameter relationship of $O$. marmorata in Sermo Reservoir

\section{Discussion}

Marble goby caught in Sermo Reservoir varied in size that is $12.0-38.2 \mathrm{~cm}$ for the male and $12.2-44.5 \mathrm{~cm}$ for the female. In comparison, male and female marble goby in Rawa Jombor has a maximum length of $34.3 \mathrm{~cm}$ and $42.7 \mathrm{~cm}$, respectively [9]. Feed availability and water quality are considered as an important factor in fish growth. A high growth rate might indicate abundant feed and adequate living environment conditions. Fish that less than $12 \mathrm{~cm}$ was not caught due to their size that enable them to hide in dense vegetation and escape from the net $[3]$.

The length-weight relationship of male and female marble goby in Sermo Reservoir represented positive allometric growth $(\alpha=0.05$ and $b \neq 3)$, indicated a faster weight increase than length (Fig.4). The condition factor represents fish corpulence in numbers based on the length and weight data. Overall, marble goby condition in Sermo Reservoir was good as more 
than $50 \%$ of the fishes had $\mathrm{Kn} \geq 0.95$ (Figure 6), indicated the fish's ability to survive and to utilize feed in its surroundings. Condition factor can also serve as an indicator for fish growth in the aquatic region, to measure environmental suitability, as well as to compare various habitats. The results confirmed that Sermo Reservoir was suitable for marble goby. The relative condition factor of female fish was higher than the male, which might indicate a better condition of female than male. The relative condition factor of marble goby in Sermo Reservoir was lower than those found in Rawa Jombor, Klaten, ranged at 0.273-2.256 $($ mean=1.016) for male and at 0.128-1.765 (mean=1.019) for female [9]. The higher relative condition factor of marble goby in Rawa Jombor was probably due to higher productivity and feed availability caused by shallow water and denser vegetation which facilitates the growth of marble goby. The deficient condition factor of marble goby $(\mathrm{Kn}<0.95)$ in April was probably caused by a lower rainfall rate which reduces Sermo Reservoir water volume. Lower water surface might affect the availability of small fish as marble goby main feed. Spawning also occurred around this month hence body weight decreased. January and February is the rainy season, thus fish biomass rapidly increases during high water surface [10], during which spawning period occurred for marble goby and certain fish, that small fish as marble goby main feed become abundant. The peak season for spawning for most tropical fish species occurred when water is abundant or flooded [11]. The peak for Kn was also caused by a high level of fish gonadal maturity ready for spawning. Marble goby is able to spawn throughout the year with the peak at the start of the rainy season when water surface increase [12].

Otolith was used to measure fish development as otolith length growth linear to fish length. The total length-otolith diameter relationship of marble goby was modeled in $\mathrm{Y}=0.0248 \mathrm{X}+0.2235$ equation, indicated that fish length increase was followed by a larger otolith diameter. Correlation among length-otolith diameter relationship was strong $(r=0.8779)$, which showed that the increase of otolith diameter was closely related to body length growth, suggested strong indication that otolith can be used to predict age and growth of marble goby. Increasing otolith diameter is caused by calcium carbonate accumulation as fish metabolic product [13]. Beside fish length growth, temperature also plays an important factor that affects fish growth hand the increase of otolith daily circle. The daily circle of fish otolith and fish growth might be inhibited and even stopped by the low temperature of habitat [14]. Length-weight relationship and length-otolith diameter relationship can be used to predict fish length from otolith diameter and fish weight from length using the obtained model equation.

\section{Conclusion}

Male and female marble goby in Sermo Reservoir had positive allometric growth, modeled by the equation of $\mathrm{W}=0.0056 \mathrm{~L}^{3.2894}$ for male and $\mathrm{W}=0.0051 \mathrm{~L}^{3.311}$ for female. Marble goby in Sermo Reservoir was generally in good condition $(\mathrm{Kn} \geq 0.95 ; 70.14 \%)$, with the highest proportion of relative condition factor $(\mathrm{Kn}>1.05)$ in February male and January female. Marble goby otolith was ovate shaped with sinuate edge and moderate thickness. Length otolith diameter relationship in marble goby was linear, modeled in equation of $\mathrm{Y}=0.2335+0.0248 \mathrm{X}(\mathrm{r}=0.938)$.

\section{References}

1. W. J. Rainboth. Fishes of the Cambodian Mekong. Food and Agriculture Organization of the United Station, Rome (1996). 
2. L. S. Vann, E. Baran, C. Phen, and T. B. Thang. Biological Reviews of Important Cambodian Fish Species, Based in Fishbase Vol. 2. Inland Fisheries Research and Development Institute (IFReDI).WorldFish Center, Cambodia (2004).

3. A. D. Utomo, and Krismono. Biological Aspect of Various Rare Fish Species in Musi River, Sumatera Selatan. Proceeding of National Seminar IV, Jatiluhur (2006).

4. E. Setyobudi, and J. Subagja Population Structure and Reproduction Potential of Tilapia (Oreochromis sp.) in Sermo Reservoir, Yogyakarta Special Province. Proceeding of National Seminar on Agriculture, Fishery, and Marine Research in Yogyakarta. Universitas Gadjah Mada (2004).

5. J. C. Schneider, P. C. Laarman, and H. Gowing. Length-weight relationship. Chapter 17 in Schneider, J. C. (ed.) 2000. Manual of fisheries survey methods II. With periodic updates. Michigan. Department of Natural Resources, Fisheries Special Report 25. Ann Arbor (2000).

6. S. P. Biswas. Manual of Methods in Fish Biology. South Asian Publishers, New Delhi (1993).

7. M. I. Effendie. Fishery Biology. Yayasan Pustaka Nusatama, Yogyakarta (1997).

8. W. E. Ricker. Computation and Interpretation of Biological Statistics of Fish Populations. Department of Environment. Fisheries and Marine Service. Ottawa, Canada (1975).

9. M. I. Sindapati. Length-weight relationship and condition factorof marble goby (Oxyeleotris marmorata Blkr.) in Rawa Jombor, Klaten District. Faculty of Agriculture. Universitas Gadjah Mada. Undergraduate thesis. Unpublished (2008).

10. R. H. Lowe-McConnell. Ecological Studies in Tropical Fish Communities. Cambridge: Cambridge University Press (1987).

11. R. L. Welcomme. River fisheries. Food and Agriculture Organization of the United Nations, FAO Fisheries Technical Paper 262 (1985).

12. K. Fatah, and S. Adjie. Biology Reproduction of Marble goby (Oxyeleotris marmorata) in Kedung Ombo Reservoir, Jawa Tengah Province. BAWAL. 5 (2): 89-96 (2013).

13. S. E Campana, and J. A. Gagne, and J. Mondro. 1978. Otolith Microstructure of Larval Hering (Clupeaharengus). Can. Fish. Aquat. Sci. 44:11-13 (1978).

14. J. D. Neilson, and G. H. Geen. Effects of Feeding Regimes and Diet Temperature Cycles on Otolith Increment Formation in Juvenile Chinook Salmon (Oncorhynchus tshawytscha). Fish Bull (Wash D C) 83:91-101 (1985). 